\title{
An Analysis of Federal Incentives Used to Stimulate Energy Consumption
}

April 1981

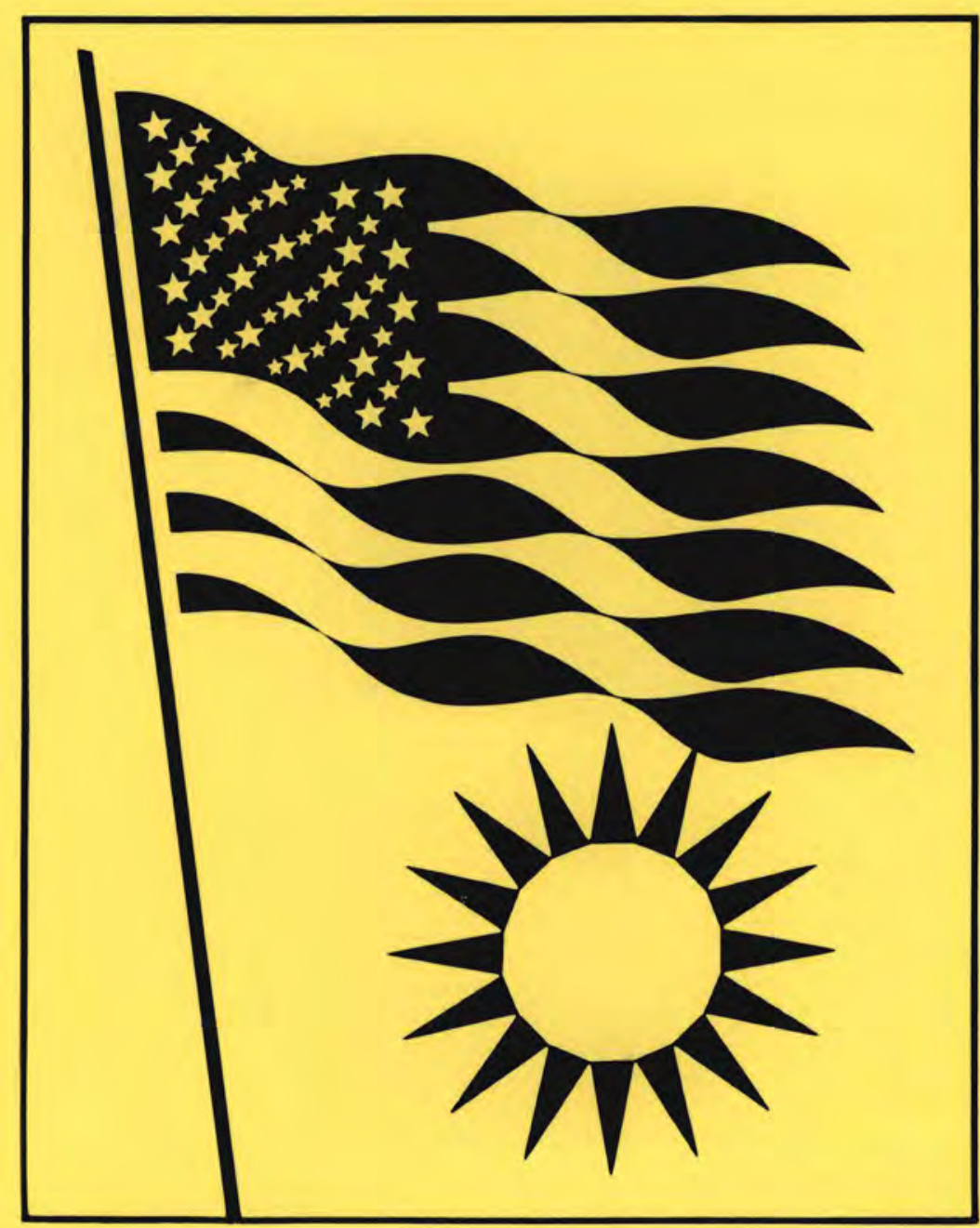

Prepared for the U.S. Department of Energy under Contract DE-AC06-76RLO 1830

Pacific Northwest Laboratory Operated for the U.S. Department of Energy by Battelle Memorial Institute 


\title{
NOTICE
}

This report was prepared as an account of work sponsored by the United States Government. Neither the United States nor the Department of Energy, nor any of their employees, nor any of their contractors, subcontractors, or their employees, makes any warranty, express or implied, or assumes any legal liability or responsibility for the accuracy, completeness or usefulness of any information, apparatus, product or process disclosed, or represents that its use would not infringe privately owned rights.

The views, opinions and conclusions contained in this report are those of the contractor and do not necessarily represent those of the United States Government or the United States Department of Energy.

\author{
PACIFIC NORTHWEST LABORATORY \\ operated by \\ BATTELLE \\ for the \\ UNITED STATES DEPARTMENT OF ENERGY \\ Under Contract DE-AC06-76RLO 1830
}

\author{
Printed in the United States of America \\ Available from \\ National Technical Information Service \\ United States Department of Commerce \\ 5285 Port Royal Road \\ Springfield, Virginia 22151
}

Price: Printed Copy $\$$ $\because$ Microfiche $\$ 3.00$

- Pages Selling Price

001-025 $\$ 4.00$

026-050 \$4.50

051-075 \$5.25

076-100 $\$ 6.00$

$101-125 \quad \$ 6.50$

$126-150 \quad \$ 7.25$

151-175 \$8.00

176-200 $\$ 9.00$

201-225 \$9.25

226-250 \$9.50

251-275 \$10.75

276-300 $\$ 11.00$ 
PNL-3558 Ex. Sum.

UC-59

AN ANALYSIS OF FEDERAL INCENTIVES

USED TO STIMULATE ENERGY CONSUMPTION

An Executive Summary
R. J. Cole
B. W. Cone
J. C. Emery
M. Huelshoff
D. E. Lenerz
A. Marcus
F. A. Morris
W. J. Sheppard
P. Sommers

\section{Apri 1981}

Prepared for the U.S. Department of Energy under contract DE-AC06-76RLO 1830

Pacific Northwest Laboratory

Richland, Washington 99352 


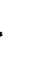

. 
CONCLUSIONS WITH RESPECT TO SOLAR ENERGY POLICY

\section{An Executive Summary}

The purpose of the analysis presented in this report is to identify and quantify federal incentives that have increased the consumption of coal, oil, natural gas, and electricity. An analysis of public incentives can form the basis of initial insights into the kind, quantity, and duration of incentives to stimulate the use of renewable energy resources. This summary is intended as a device for presenting the policy questions about the incentives that can be used to stimulate desired levels of energy development. Decisions about incentives involve not only dollars, but also types of incentives, particular technologies, intended user groups and the timing of incentives.

The estimates of past incentives presented can be useful in framing new incentive programs in three ways. First, the rationales used to justify historical programs may be useful in arguing for new programs. Rationales of aid to infant industries, moving an industry along a learning curve more rapidly, and aiding particular social or geographical groups may be applicable to solar industries. Second, the mechanisms used to provide incentives in the past are basically tools that are available at present. Our research is one of the few attempts to develop a theory of how the government can give incentives, and to provide data on the efficacy of using various theoretically available "tools." Third, the data on historical use of various incentive types provides indicators of preference for one type versus another. These data can be guides to policy makers as they consider how to implement new incentive programs.

The conclusions about past incentives can be a guide in choosing the particular incentives that deserve careful consideration in the years ahead. It is intended as a point of departure in the process of achieving a national goal through the interaction of scientific inquiry and public debate. If it is socially desirable and technologically feasible to increase solar energy's share in the national energy budget, the paramount 
policy question is one of selecting an incentive strategy and determining the government's level of investment in it.

Federal incentives for the consumption of energy are Federal Government actions whose major intent or major result is to stimulate energy consumption. The stimulus comes through changing values of variables included in energy demand functions, thereby inducing energy consumers to move along the function in the direction of greater quantity of energy demanded, or through inducing a shift of the function to a position where more energy will be demanded at a given price. The demand variables fall into one of six categories: (1) price of the energy form, (2) price of complements, (3) price of substitutes, (4) preferences, (5) income, and (6) technology.

The government can provide such incentives using six different policy instruments defined in the introductory chapter: (1) taxation, (2) disbursements, (3) requirements, (4) nontraditional services, (5) traditional services, and (6) market activity. We examined four energy forms: (1) coal, (2) oil, (3) natural gas, and (4) electricity. And we examined six energy-consuming sectors: (1) residential, (2) commercial, (3) industrial, (4) agricultural, (5) transportation, and (6) public.

When all energy incentive actions taken during fiscal year 1978 were analyzed it was found that the overwhelming proportion of these incentives are classified as "incentives with non-energy related intent." Funds used to construct highways, operate government buildings, and transport government personnel have major influences on national energy consumption patterns. The Federal Government is the single largest energy consumer in the economy. However, the primary intent of these programs has little to do with shaping energy consumption patterns. Total non-energy intent incentives amounted to $\$ 28.8$ billion in 1978 . About $47 \%$ of these funds consisted of market activity to operate government buildings and to transport government personnel. Disbursements accounted for nearly $44 \%$ of these funds, and traditional and nontraditional accounted for over $9 \%$. Incentives with energy related purposes amounted to $\$ 2.3$ billion in 1978 . Nearly $91 \%$ of these incentives were for 011 consumption, with solar and 
other nontraditional energy forms receiving $8 \%$, and the remaining traditional energy forms (coal, gas, and electricity) each receiving less than $1 \%$ each. Almost half $(42.1 \%)$ of the incentives with energy related intents were in the form of tax exemptions, and more than a third (38.5\%) took the form of market activity incentives. The remainder of the incentives are divided among disbursements $(12.2 \%)$, requirements $(5.0 \%)$, and traditional and nontraditional services (2.2\% together). Thus, the 1978 spending patterns suggest a concentration of incentives with energy intent in taxation and market activity. The incentives with non-energy intent were concentrated in disbursements and market activity for the most part, and required almost fifteen times as much funding as the incentives with energy related intent. Since several purposes, both explicit and implicit, are served by these actions, it is not surprising to find higher spending levels.

Our analysis shows that the Federal Government has expended $\$ 170.4$ billion for incentives to stimulate energy use. This figure, and all of the estimates below are the undiscounted sum of spending in relevant categories over the period 1950-1978 (unless some other period is specified), reported in constant 1978 dollars. (No discounting of incentives was done on the grounds that many incentives have cumulative effects over long time periods; they are public sector "investments" whose effects are felt over long periods of time in both the private and public sectors.) These expenditures are presented in Tables 1 and 2 according to energy form, incentive type, and user sector.

\section{Energy Forms}

As shown in Table 1, $0 i 1$ consumption received the largest share of incentive funds (75\%), more than twice the share of any other energy form. The second largest share of federal incentives (23\%) went to the promotion of electricity consumption. Coal received about $2 \%$ of the consumption incentive dollars, while natural gas received only $0.1 \%$. 
TABLE 1. An Estimate of the Cost of Incentives Used to Stimulate Energy Consumption, by Incentive Type and Energy Source (Millions of 1978 Dollars)

\begin{tabular}{|c|c|c|c|c|c|c|}
\hline & Coal & $0 i 1$ & Gas & Electricity & Total & $\begin{array}{l}\text { Percentage of } \\
\text { Total Incentives }\end{array}$ \\
\hline Taxation & & 28,086 & & & 28,086 & 16.4 \\
\hline Disbursements & & 3,466 & 201 & 6,959 & 10,626 & 6.2 \\
\hline Requirements & 10 & 80,414 & & & 80,424 & 47.2 \\
\hline Traditional Services & & $15,825^{(a)}$ & & & 15,825 & 9.3 \\
\hline Nontraditional Services & 3030 & 75 & & 242 & 3,347 & 2.0 \\
\hline Market Activity & & & & 32,113 & 32,113 & 18.8 \\
\hline Totals & 3,040 & 127,866 & 201 & 39,314 & 170,421 & 100.0 \\
\hline $\begin{array}{l}\text { Percentage of Total } \\
\text { Incentives }\end{array}$ & 1.8 & 75.0 & 0.1 & 23.1 & 100.0 & \\
\hline
\end{tabular}

(a) Negative value of highway trust fund omitted ( $\$ 60.6$ billion). 
TABLE 2. An Estimate of the Cost of Incentives Used to Stimulate Energy Consumption, by Incentive Type and Sector (Millions of 1978 Dollars)

\begin{tabular}{|c|c|c|c|c|c|c|c|c|}
\hline & Residential & Commercial & Industrial & Transportation & Agricultural & Public & Total & $\begin{array}{l}\text { Percentage of } \\
\text { Total Incentives }\end{array}$ \\
\hline Taxation & & & & 24,130 & & 3,956 & 28,086 & 16.4 \\
\hline Disbursements & 415 & & & 10,211 & & & 10,626 & 6.2 \\
\hline Requirements & 12,749 & (a) & $30,634^{(b)}$ & 34,655 & & 2,386 & 80,424 & 47.2 \\
\hline Traditional Services & & & & $15,825^{(c)}$ & & & 15,825 & 9.3 \\
\hline Nontraditional Services & & & 3,105 & 242 & & & 3,347 & 2.0 \\
\hline Totals & 13,201 & 16 & 45,688 & 85,063 & & 26,453 & 170,421 & 100.0 \\
\hline $\begin{array}{l}\text { Percentage of Total } \\
\text { Incentives }\end{array}$ & 7.7 & 0.0 & 26.8 & 49.9 & & 15.5 & 100.0 & \\
\hline
\end{tabular}


Incent ive Types

As shown in the rows of Table 1, the largest proportion of incentives were in the form of requirements (47.2\%). Market activity was the second most common incentive type $(18.8 \%)$, with taxation a close third $(16.4 \%)$. Traditional services $(9.3 \%)$ and disbursements $(6.2 \%)$ were roughly comparable in magnitude; nontraditional services accounted for just $2 \%$ of incentive costs. Note that in the cumulative estimates, incentives with energy intents are mixed with those with other intents, whereas these two types of energy incentives have been analyzed separately in the analysis of incentives in 1978.

Comparing these cumulative incentive figures to the single year estimates, the relative roles of taxation, requirements, and disbursements appear to differ greatly. Taxation received greater emphas is in 1978 than in the average over a 11 previous years. Requirements are larger in the cumulative estimates. Disbursements play a larger role in the 1978 estimates, but are found mostly in the category of incentives with non-energy intent.

\section{User Sectors}

Looking at the sectors (see Table 2), it is clear that transportation got the largest part, nearly $50 \%$ of a 11 incentives. Large items are crude oil price controls, and aviation subsidies. (This estimate excludes federal highway programs, which have helped increase the use of motor fuel, but have collected more in highway user taxes than have been spent.) Industry has gotten the next largest allocation (26.8\%), primarily from crude oil price controls and sales of government produced electricity at low prices. Government use of government produced electricity is another large item, which contributes to the public sector estimate of $15.5 \%$ of total incentives. The residential sector received just $7.7 \%$ of the incentive funds. The low estimate of incentives for the commercial and agricultural sectors is partly a data problem. Commercial use of oil could not be separated from residential oil use, and non-transportation agricultural oil use could not be separated from industrial oil use. The transportation estimate is complicated by the fact that some of it is really commercial, industrial, agricultural, and 
personal consumption activity. Only government transportation could be disaggregated from the totals.

Demand Determinants

Examples of the use of all of the demand determinants identified in traditional economic analysis. The largest determinant of demand has been price, principally through requirements (price controls for crude oil) and market activity (sales of electricity from federal projects). Technology determinants are next, the largest item being improvements in airports and aviation facilities. Income determinants, in the form of disbursements, and changes in the price of complements have had a minor role. Preference determinants of demand have had a small budgetary cost but involve federal programs with legal requirements, such as enforced switching to coal. The cost to a violator could be very high.

\section{AN APPROACH TO SOLAR INCENTIVES}

The analysis of historical use of incentives for traditional energy forms suggests a number of guidelines for solar policy. We do not expect history to repeat itself precisely, but neither do we expect historical patterns to be suddenly and widely disrupted. Thus, our examination of historical incentives used to stimulate the consumption of coal, oil, natural gas, and electricity suggests some guidelines and limits for the use of incentives to stimulate consumption of solar energy.

Several conclusions for solar policy are clearly related to the data we have assembled. That is, we suggest that direct analogues to historical policies may exist in some cases. Many of the programs which stimulated use of traditional energy forms were not directly energy programs, but had other purposes. As side effects, or second-order impacts, such programs as highway construction, port construction, and government use of energy have had powerful influences on national energy consumption patterns. A solar policy analogue is encouragement of solar power as an energy source in re-industrialization programs.

A major conclusion from this volume is that substantial incentives have been given to stimulate consumption of energy, $\$ 170$ billion. 
Previous research has established that production incentives were also provided, amounting to $\$ 252$ billion over the same period. (1) The historical incentive patterns suggest that it is not necessary to choose between supply-push and demand-pull strategies for stimulating new industries. The historical pattern in the energy sectors is to stimulate both sides of the market. In addition, the incidence of the incentive frequently is shifted from one sector to the other, making the distinction somewhat blurred.

Another important type of traditional action which government could consciously use to stimulate solar consumption is to specify solar space conditioning and electric power systems in selected government facilities. Such solar systems are cost competitive in a few installations at present. Furthermore, a dramatic decrease in cost as production increases (learning-curve phenomena) for some solar technologies (photovoltaics) could allow early Federal Government purchases in significant volumes, even at higher than competitive prices, to bring down costs in the future to the point that very widespread market penetrations will be possible. The Federal Government, as the single largest energy consumer in the economy, and as a major energy producer and major element of capital markets, can be very influential in shaping the future of solar energy through selective use of market activities.

More general guidelines for solar incentives also stem from this research. Traditional energy sources have been significantly stimulated by a variety of types of incentives given to both producers, as demonstrated in previous research, (2) and to consumers, as demonstrated by the estimates in this study. In order to compete we11, solar energy will require similar governmental stimulation to overcome the cumulative effects of past stimulation of other energy forms and to offset on-going stimulation of other energy forms. The amount of spending on traditional energy forms, over $\$ 170$ billion in consumption incentives and $\$ 252$ in production incentives, may provide a rough guide to the magnitude of spending on solar incentives that will be required to achieve particular solar production targets. 


\section{NOTES - CHAPTER VIII}

1. B. W. Cone et a1., An Analysis of Federal Incentives Used to Stimulate Energy Production. Report for the U.S. Department of Energy by Pacific Northwest Laboratory (PNL-2410 REV. II), February, 1980.

2. B. W. Cone et al., February, 1980. 

PNL-3558 Ex. Sum. UC -59

\section{DISTRIBUTION}

No. of

Copies

OFFSITE

A. A. Churm

DOE Patent Division

9800 S. Cass Avenue

Argonne, IL 60439

25 James C. Easterling

DOE Division of Conservation and Solar Energy

Office of Solar Applications for Industry

600 E Street N.W.

Washington, DC 20585

27 DOE Technical Information Center

Robert L. Sears

Associate Director, ASEC

$1700 \mathrm{~W}$. Washington, \#502

Phoenix, AZ 85007

Michael Saba

Theodore Barry \& Associates

1520 Wilshire

Los Angeles, CA 90017

Gerald Bennington

Bennington Enterprises, Ltd.

P. 0. Box 866

Vienna, VA 22180

John Emery

Bonneville Power Administration

Box 3621

Portland, OR 97208

William Babcock

Booz, Allen \& Hamilton, Inc.

311 First Street, N.W.

Washington, DC 20001
No. of

Copies

Richard Chew

300 Radio Building

2030 North 16th Street

Arlington, VA 22201

Bruce W. Cone

Rt. 2, Box 2142

Benton City, WA 99320

Jeff Hammarlund

U.S. Department of Energy

CS-PP\&E

Rm 6B-042

Mail Stop 6B-025

1000 Independence Avenue, S.W.

Forrestal Building

Washington, DC 20585

Mr. Charles R. Hauer

U.S. Department of Energy 1000 Independence Avenue S.W. Washington, DC 20585

Lee Johnson

U.S. Department of Energy,

Region $X$

1992 Federal Building

915 Second Avenue

Seattle, WA 98174

Dr. Roger Bezdek

Department of Treasury

15 th and Penn N.W.

Room 4120

Washington, DC 20220

Sarah Glazer

Subcommittee on Energy and Development Applications

B374 Rayburn House Office Building Washington, DC 20515 
No. of

Copies

James W. Spensley

Staff Director

Subcommittee on Energy and

Development Applications

B374 Rayburn House Office

Building

Washington, DC 20515

Arthur J. Reiger

Director of Financial Analys is

HUD Solar Demonstration Program

Department of Housing and Urban Development

Room 8158

Washington, DC 20410

Rosalyn Barbieri

Jet Propulsion Laboratory

4800 Oak Grove Drive

Pasadena, CA 91103

James Maxwe 11

Massachusetts Institute of Technology

Center for Policy Alternatives

Cambridge, Massachusetts 02139

Alex Maurizi

1344 Fitch Way

Sacramento, CA 95825

Michael Huelshoff

Department of Political Science

University of Michigan

Ann Arbor, MI 48109

Michael Shulman

W392

The MITRE Corporation

1820 Dolly Madison Boulevard

McClean, VA 22012

Alan Miller

Natural Resources Defense

Council

1725 I Street, N.W.

Suite 600

Washington, DC 20006
No. of

Copies

Eric 0lson

Northeast Solar Energy Center

470 Atlant ic Avenue

Boston, MA 02110

Thomas Sparrow

School of Industrial Engineering

Grissom Hall

Purdue University

West Lafayette, IN 47907

Jon M. Veigel

SERI

1617 Cole Boulevard

Golden, CO 80401

Barbara Euser

Solar Energy Research Institute

1536 Cole Boulevard

Golden, Colorado 80401

John N. Nassikas

Squire, Sanders and Dempsey

21 Dupont Circle N.W.

Washington, DC 20036

Raymond G. Anderson

Washington State Energy Office

400 E. Union Street, Ist Floor

Olympia, Washington 98504

Dr. Leon Lindberg, Professor

Department of Political Science University of Wisconsin-Madison 1050 Bascom Hall

Madison, WI 53706

ONS ITE

DOE Richland Operations Office Programs Division

H. E. Ransom 
No. of

Copies

30 Pacific Northwest Laboratory

P. Cohn

T. Willke (10)

R. Cole (HARC) (10)

D. Deonigi

J. Emery

A. Fassbender

H. Harty

A. Marcus

R. Mazzucchi

P. Petty

P. Sommers (HARC)

L. Williams

Technical Information (5)

Publishing Coordination RO (2)

Barbara Keen (HARC) (2)

11 Battel le-Columbus Laboratories

D. Lenerz

W. Sheppard (10)

FOREIGN

Battel le-Geneva

Claude Massetti

Battel le-Frankfurt

Shirley Van Buiren

Distr-3 


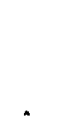

